\title{
New Format of the Final State Examination at Bachelor Graduates in the Field of «Pedagogical Education»
}

\section{Nuevo formato del examen final de estado en licenciados en el campo de la «educación pedagógica»}

\author{
Elena N. Perevoschikova" \\ Department of Mathematics and Mathematical Education, Kozma Minin Nizhny Novgorod \\ State Pedagogical University, Nizhny Novgorod, Russia. \\ ORCID: https://orcid.org/0000-0002-2711-9744 \\ Anastasia V. Stafeeva \\ Department of Physical Education Theoretical Foundations, Kozma Minin Nizhny Novgorod \\ State Pedagogical University, Nizhny Novgorod, Russia. \\ ORCID: https://orcid.org/0000-0002-8720-7447 \\ Ekaterina Y. Elizarova \\ Department of Mathematics and Mathematical Education, Kozma Minin Nizhny Novgorod \\ State Pedagogical University, Nizhny Novgorod, Russia. \\ ORCID: https://orcid.org/0000-0002-1348-3908

\section{Irina Y. Burkhanova} \\ Department of Physical Education Theoretical Foundations, Kozma Minin Nizhny Novgorod \\ State Pedagogical University, Nizhny Novgorod, Russia. \\ ORCID: https://orcid.org/0000-0002-7954-2341 \\ Tatyana K. Belyaeva \\ Departments of General and Social Pedagogy, Kozma Minin Nizhny Novgorod State \\ Pedagogical University, Nizhny Novgorod, Russia. \\ ORCID: https://orcid.org/0000-0001-6096-9452
}

Received 0-12-20 Revised 01-25-20 Accepted 04-13-20 On line 06-29-20

*Correspondence

Email: perevoshikovaen@mail.ru
Cite as:

\footnotetext{
Perevoschikova, E.N., Stafeeva, A.V., Elizarova, E.Y., Burkhanova, I.Y., \& Belyaeva, T.K. (2020). New Format of the Final State Examination at Bachelor Graduates in the Field of «Pedagogical Education». Propósitos y Representaciones, 8 (SPE2), e793. Doi: http://dx.doi.org/10.20511/pyr2020.v8nSPE2.793
} 


\section{Summary}

The purpose of this study is to build a model of fund tasks aimed at assessing general professional and universal competencies of bachelor's graduates studying in the field of training «Pedagogical education» at the stage of preparation and conduct of the final state exam. Systemic, actionoriented, competency-based and contextual approaches were used as methodological guidelines in the development of fundraising tasks. The authors defined the notions of "fund task", "key actions" and highlighted the types of fund tasks, justified the need to change the form and content of evaluation tools used in the preparation and conduct of the final state exam.

Keywords: fund task model, key action, structure of the final state exam, competence assessment

\section{Resumen}

El propósito de este estudio es construir un modelo de tareas de fondos destinadas a evaluar las competencias profesionales y universales generales de los graduados de licenciatura que estudian en el campo de la formación «Educación pedagógica» en la etapa de preparación y realización del examen estatal final. Se utilizaron enfoques sistémicos, orientados a la acción, basados en competencias y contextuales como pautas metodológicas en el desarrollo de tareas de recaudación de fondos. Los autores definieron las nociones de "tarea de fondos", "acciones clave" y destacaron los tipos de tareas de fondos, justificaron la necesidad de cambiar la forma y el contenido de las herramientas de evaluación utilizadas en la preparación y realización del examen estatal final.

Palabras clave: modelo de tarea de fondos, acción clave, estructura del examen estatal final, evaluación de competencia.

\section{Introduction}

One of the urgent tasks of modern pedagogical education is to establish the quality of training of bachelors of pedagogical education, which is determined on the basis of assessment of graduates' competencies at the stage of final certification in the training profile.

The analysis of existing programs of the final attestation of bachelor's graduates in the direction «Pedagogical education», the study of the practice of the state final attestation, the comparison of real results with the requirements of the Federal State Educational Standard to assess the readiness of graduates for professional activity, allowed the authors to formulate a number of existing problems in organizational, substantive and control and evaluation aspects of the final attestation of future teachers. The authors have formulated the following problems, which condition the relevance of the study: the lack of conformity of assessment tools presented in the programs of final state certification of graduates to the requirements formulated in the Federal State Educational Standard, not developed new forms of the final state exam, the lack of concept of creating tools to assess the formation of competencies of graduates at the stage of the final state exam. On the basis of the identified unresolved problems, the authors have formulated the research objective: to develop a new format of the final state exam, and a new model for the construction of evaluation tools aimed at assessing the formation of competencies of bachelor 
graduates in accordance with the Federal State Educational Standard of Higher Education in the field of training «Pedagogical Education» (hereinafter FSES HE) (Federal state educational standard, 2018).

In the process of analysis of various programs of the final state certification it has been established that the state examination is usually held in the traditional form by tickets. The tickets include the wording of one or two topics from the academic discipline and standard tasks for the application of theoretical facts. Therefore, the final assessment is made based on the results of these types of tasks and is determined based on criteria related to the characteristics of the mastered knowledge. Since there may be several disciplines for which questions are selected for the final state examination, the developer of programs of the final state certification must select a limited number of topics that are submitted to the state exam. Naturally, the question arises as to the criteria for such selection. At the same time, it should be considered that many disciplines in the profile of training of a graduate provide for course exams, and sometimes final exams in the discipline studied several semesters. Consequently, if one of the goals of preparing a graduate for the final state attestation is to generalize and systematize the studied material, then the questions at the state exam cannot repeat those that were in the frames of intermediate attestation by disciplines. It follows that even with the traditional form of the state examination, the questions should be of a different plan and reflect a new level of mastery of the complex of disciplines in the training profile. In studying this question, the authors turned to a new form of certification of young teachers based on unified federal evaluation materials tested in 2018 (Gustyakhina, 2009; Exam for teachers: how well will the job for certification, 2020). The introduction of the new form of certification of young teachers at the entrance to the profession was the basis for revising the existing form of the final state exam and led to the conclusion that the structure of the final state exam should be distinguished by two interrelated parts, including testing for the disciplines of subject training and performance of the context task in the training profile. For the development of substantive and organizational-methodical foundations for the construction of contextual tasks to assess the formation of general professional and universal competencies required the development of a model of universal examination tasks, which are named in the article stock tasks.

\section{Methodological Framework}

The methodological basis of the research is defined by systemic, activity, competence and contextual approaches to learning and the methods that make them up, which allow to reveal the specifics of assessing educational results.

Within the limits of the system approach (Blauberg \& Yudin, 1973; Trushnikova, 2006) the final certification of graduates is considered as a system object. From these positions in the research the correlation of two internal forms of attestation within the limits of the final state examination is established, the possibility of establishment of interrelation between internal and external factors of realization of final attestation of the graduate of pedagogical higher education institution and his employment as a young specialist in educational institution is revealed. 
The concept of evaluation tools development is based on the activity approach (Khutorskoy, 2003; Kasprzhak \& Kalashnikov, 2014; Korshunova, 2014), which implies the description of educational results through the types of pedagogical activities, the possession of which should be demonstrated by a graduate at the stage of final state certification. The reliance on the activity approach in combination with the system approach has served as a basis for the implementation of the following principles in the selection and design of examination (fund's) tasks.

On the basis of the principles of integrity, expediency and comprehensiveness, the structural model of the universal examination task has been determined, and specific features of the use of fund tasks in the preparation and holding of the final state exam (hereinafter "FSE") for the graduates of the pedagogical university have been revealed.

The principles of purposefulness, universality and comprehensiveness are realized at the stage of development of evaluation tools for carrying out the FSE by filling with the content of organizational-methodical and control and evaluation components that make up two parts of the form of examination task. These parts are oriented to the profile of the graduate training and provide the universality of the examination task. The content essence of the evaluation tool, related to the subject area of the graduate's training, is defined by the teachers, who provide the subject and methodical training of the student.

The change in the orientation of assessment of educational results from the concept of "preparedness" to the concept of "competence" characterizes the specificity of the competence approach in education. From the point of view of this approach (Efremova, 2012; Aizenstat \& Stebleva, 2018; Rebrin, 2014) to the evaluation of educational results in the study there is built a model of fund task, possible combinations of general professional and universal competencies in accordance with the indicators of their achievement are determined.

Reliance on the Context Approach to Training served as a basis for the use in the study of methods and techniques of constructing context problems (Verbitsky \& Kalashnikov, 2010; Perevoshchikova \& Lekomtseva, 2016; Modernization of the educational process, 2016). The structure of contextual problems includes a description of practice-oriented situations related to the professional activity of a graduate of a pedagogical university.

\section{Results}

As a result of the research we have defined a new format of the final state examination of bachelor's graduates in the field of «Pedagogical education», built a model of stock tasks, determined the types of stock tasks. Let us characterize the mentioned results.

It is proposed to separate two parts in the structure of the final state examination. The first part provides testing by disciplines of subject preparation of the graduate. This part should be aimed at checking whether a graduate has professional (special) competences. The second part is a test aimed at a graduate's performance of an exam assignment included in the fund of assessment tasks. Such tasks in the study are called fund's tasks. By "fund's tasks" we mean a task aimed at evaluating a graduate's readiness for professional activity. It is constructed in accordance with the requirements of FSES HE to the formation of general professional and universal competencies. 
In the process of their design, the requirements of the Professional Standard for a young teacher at the stage of entering the professional activity are considered.

The fund's tasks are constructed as context tasks, the structure and content of which were defined earlier in our work «Modernization of the Educational Process, 2016» (Modernization of the educational process, 2016; Gruzdeva \& Tukenova, 2019; Markova \& Narkoziev, 2019). Organizational issues on the implementation of such a format of the final state exam are solved with the help of the e-learning environment of the University. In system «moodle» sets of tests are prepared and fund's tasks are placed in the e-learning environment of the University for six months before the beginning of final state certification of graduates. The process of testing and presentation of the results of the fund's tasks is carried out at the FSE.

To build a model of a fund's task, an analysis of the content of competencies presented in FSES HE was carried out, based on which it was concluded that the «core» of each fund's task should be one of the general professional compositions GPC-1 - GPC-7. It was established that the GPC-8 competence and all its components should complement each of the selected general professional competencies, as they reflect the ability of a graduate to operate with scientific knowledge. Based on these competencies, a situation is formulated in which a graduate must prove himself or herself, perform the required tasks and actions. Variation of tasks-questions to the proposed situation is performed in accordance with the selected indicators of these competencies. Universal competencies are selected in such a way as to supplement or extend the leading activity envisaged in the story and the requirements to the task. Therefore, the selection of universal competence (UC) and the corresponding indicator of its achievement allows to construct a third question to the task on the situation presented in the stock task. This approach to the construction of the fund's task is the basis of the universal model of the fund's task (Fig. 1).

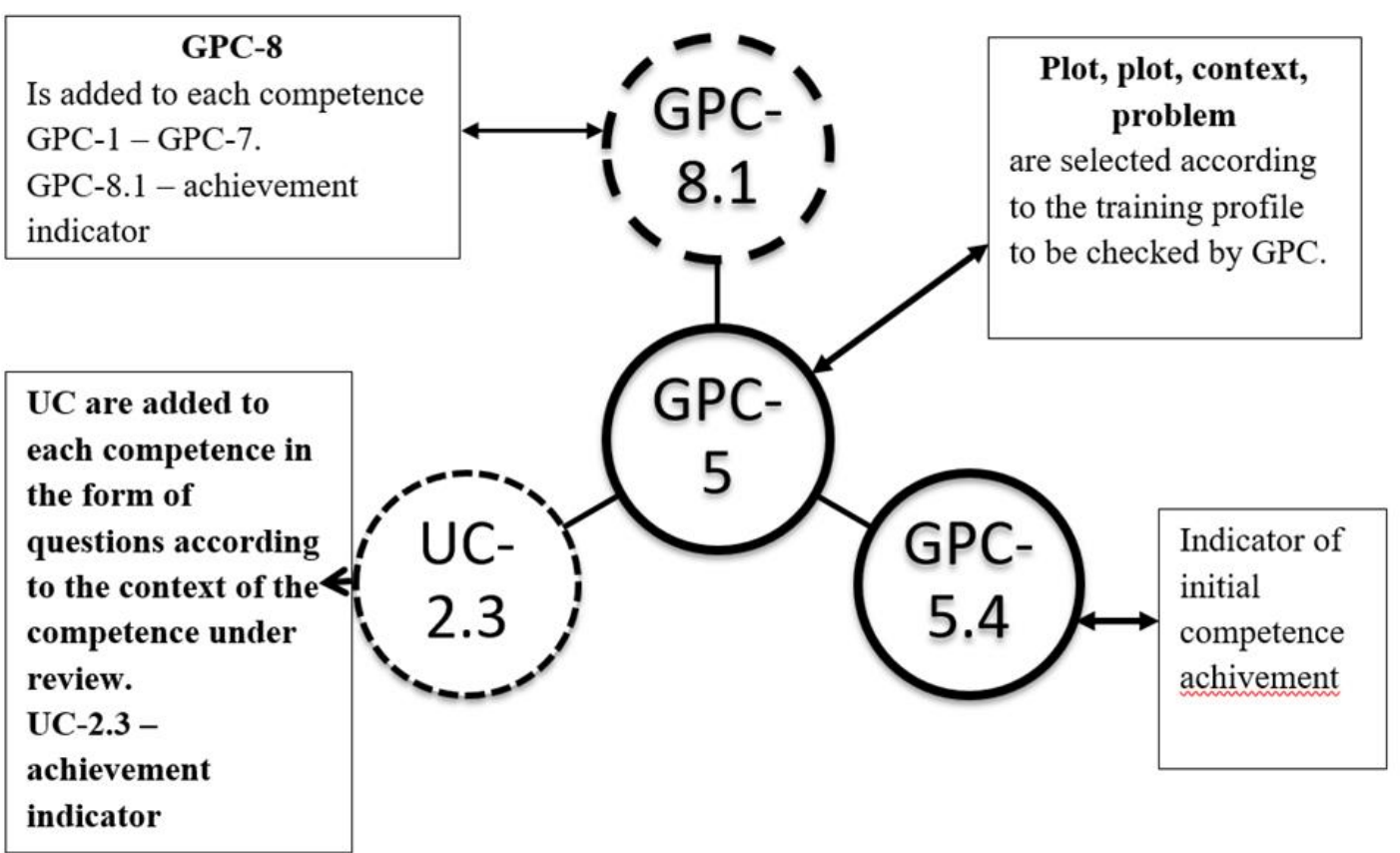

Figure 1. Module of a fund's tasks 
Figure 1 shows the model of the fund's task, based on the general professional competence GPC-5: Capable of monitoring and evaluating the formation of educational results of students, identify and correct learning difficulties (Federal state educational standard, 2018). The characterization of this competence allows to determine the situation in which the graduate is to act. As a basis for constructing questions to the situation described in the fund's task, we relied on the concept of «key action». By key actions we mean the actions of a graduate related to the baseline GPC around which other actions are grouped, reflecting different aspects of the implementation of a key action. The key actions identified from the GPC-5 analysis include demonstrating the ability to identify and correct learning difficulties, mapping the control activity analysis, identifying typical student errors in control tasks, and developing a plan of corrective actions to overcome the identified difficulties. The specified actions can be specified all or separately in the text of the stock task. These key actions and show the graduate what he or she needs to do in each situation, define the area of manifestation of his or her abilities. Thus, selecting a key action allows you to set the types of fund's tasks based on one of the GPC.

Further, the specifics of a task in accordance with the GPC-5 can be disclosed by selecting one of the indicators of achieving this competence. As an example, Figure 1 shows an indicator of achievement of this competence GPC-5.4: formulates the identified difficulties in learning and corrects the ways to achieve educational results (Approximate basic educational program, 2017).

The necessity of selection of this indicator is dictated by the requirements of the Professional standard of a teacher, which assigns a labor action for the implementation of the general pedagogical function "Teaching", A/01.6. labor action 6: Organization, monitoring and evaluation of educational achievements, current and results of the main educational program by student (Professional standard, 2013). The chosen indicator of achievement allows formulating the following requirement in the fund's task: «Select the errors that may have resulted in wrong answers. Specify the reasons for these errors».

To construct the next question, it is proposed to use one of the competence indicators of GPC.8.1: demonstrates special scientific knowledge, including in the subject area. This indicator allows, for example, the following fund's task requirement to be formulated: complete control tasks, provide an informed decision and answer. Draw up a diagram of the control activity analysis.

The formulation of the third question to fund's is determined on the basis of universal competence and relevant indicators of its achievement. Thus, Figure 1 shows the UC.2.3 indicator: demonstrates the ability to determine the available resources to achieve the project goal. Binding this indicator to the key actions of the GPC-5 allows you to formulate the following requirement: Propose and justify a plan of corrective measures to eliminate errors made by students in the control work.

Thus, after definition of objects of check in the form of professional kinds of activity of the graduate, formulation of requirements to fund's task the control and estimation part on each stock task is defined.

The assessment criteria are built according to the competence evaluation method developed by us (Perevoshchikova \& Lekomtseva, 2016; Perevoshchikova, 2016) and presented in Table 1. 
Table 1. Final assessment of graduates' competence formation in the final state exam

\begin{tabular}{|c|c|}
\hline Form & Boundaries on points \\
\hline Testing (special competences) & $15-30$ \\
\hline Fund's task & $40-70$ \\
\hline Total & $55-100$ \\
\hline
\end{tabular}

To summarize, let's present an example of fund's task, built based on the presented model. The structure of fund's task is constructed in accordance with the form of presentation of evaluation tools, which includes three parts: organizational-methodical, substantive and control and evaluation (Verbitsky \& Kalashnikov, 2010; Perevoshchikova et al., 2019).

Fund's task for GPC-5 presented below and consists of three parts.

Part 1. Organizational and methodological.

GPC-5. Capable of monitoring and evaluating the formation of students' educational results, identifying and correcting learning difficulties.

GPC.5.4. Formulates the identified learning difficulties and adjusts the ways of achieving educational results.

GPC.8.1. Demonstrates special scientific knowledge, including in the subject area.

UC.2.3. Demonstrates the ability to identify available resources to achieve the project goal.

The professional standard of a teacher. General pedagogical function. Training A/01.6. labor activity 6. Organization, monitoring and evaluation of educational achievements, current and results of the main educational program of students.

\section{Part 2. Content}

Task. At the end of the first half of the year, the school administration conducted tests for students in the 8th grade in your subject (test, test work, dictation, compliance, etc.). As a graduate of a teacher training university, you were asked to demonstrate your ability to identify and correct learning difficulties, map out a control activity analysis, identify typical errors in assignments, and develop a plan of corrective measures to overcome identified difficulties. Familiarize yourself with the content of the control activity and perform the following tasks 1 to 3.

1. Complete the control tasks, provide an informed decision and answer. Draw up a diagram of the control activity analysis (GPC.8.1).

2. Highlight errors that may have resulted in incorrect answers. Identify the reasons for these errors (GPC.5.4).

3. Suggest and justify a corrective action plan to address the errors identified (UK.2.3).

Part 3. Criterion and assessment

Criteria and assessment procedure. Assessment scale. 
1. The evaluation of task 1 is based on the following criteria: the degree of completeness and correctness of the task and the degree of compliance with the professional standard (Table 2). The step-up coefficient is 5 .

Table 2. Task assessment indicators

\begin{tabular}{|c|c|}
\hline Indicators & Assessment \\
\hline $\begin{array}{c}\text { The control work has been done correctly and the correct answer has been } \\
\text { received. Justification of all decision steps is given. The correct sequence of } \\
\text { actions of the teacher on drawing up the scheme of analysis of results of the } \\
\text { control work is presented. }\end{array}$ & 4 \\
\hline $\begin{array}{c}\text { The control work has been done correctly and the correct answer has been } \\
\text { received. The substantiation of only the key points of the decision is given. } \\
\text { The built analysis scheme partially meets the requirements of the task, but it } \\
\text { can be used to analyze the results of the control work. The correct sequence } \\
\text { of the teacher's actions in selection of the skills to be tested is presented. }\end{array}$ & 3 \\
\hline $\begin{array}{c}\text { The control work has been done correctly and the correct answer has been } \\
\text { received. The substantiation of only individual decision steps is given. The } \\
\text { constructed scheme meets individual requirements of the task, it cannot be } \\
\text { used without improvement. }\end{array}$ & 2 \\
\hline $\begin{array}{c}\text { The control work has been done correctly and the correct answer has been } \\
\text { received. There are no substantiations for the decision steps. The scheme is } \\
\text { not constructed or does not meet the requirements of the task. The sequence } \\
\text { of presentation of the skills to be tested is broken or their wording does not } \\
\text { meet the requirement of the task. }\end{array}$ & \\
& \\
\end{tabular}

Note. The criteria and assessment indicators for the first assignment are presented in the criterion assessment part of the example in question. Criteria and indicators for other requirements of the fund's task are built in a similar way.

So, the criterion evaluation part includes competence evaluation based on the results of each requirement included in the fund's task (Table 3)

Table 3. Assessments of fund's task fulfilment, based on GPC-5

\begin{tabular}{|c|c|}
\hline Competitions & Boundaries on points \\
\hline GPC. 8.1. & $10-20$ \\
\hline GPC.5.4 & $20-30$ \\
\hline UK.2.3. & $10-20$ \\
\hline Total & $\mathbf{4 0 - 7 0}$ \\
\hline
\end{tabular}

\section{Discussion}

Different types of fund's tasks, depending on the focus of the competence, can be used to assess general professional competencies in the final state exam. The choice of a key action makes it possible to determine the types of fund's tasks, which are based on one of the GPC. Thus, in order to assess the ability of students to participate in the development of basic and additional educational programs, develop their individual components (GPC-2), it is advisable to use such 
types of tasks as: drawing up a lesson summary or various forms of extracurricular activities. The same type of exercises can be used for conducting lesson analysis or extracurricular activities. In similar tasks the key action is the analysis of already prepared lesson summary or extracurricular activity that allows the graduate to show the abilities. These types of tasks can be offered to students in order to develop competencies related to the development of basic and additional educational programs or their individual components.

In order to assess the ability of students to organize joint and individual learning and educational activities of students, including those with special educational needs identified in the requirements of FSES HE, it is advisable to use such types of tasks as: development of plans (programs), technical technologies by graduates to study topics, sections of a particular subject area. Competence related to the formation of the ability to use psychological and pedagogical technologies in professional activities necessary for individualization of learning, development, education, including students with special educational needs can be assessed on the basis of the development of a program or technology adapted to a specific contingent of students with special educational needs.

Based on fund's tasks, which are universal in nature, the tasks are filled with specific content related to the subject area of the graduate. Such work is carried out by teachers who provide subject and methodical preparation of students.

A particular difficulty is the construction of examination tasks for the evaluation of competencies related to the evaluation of the graduate's ability to interact with participants in the educational process and the formation of spiritual and moral qualities of students (Piskunova \& Erokhina, 2017; Ignatiev, Alekseeva \& Bogushevich, 2019; Fedorov et al., 2017; Yadryshnikov et al., 2018; Yu-Fen Yang \& Nai-Cheng Kuo, 2020; Angrist \& Lavy, 2001; Darling-Hammond, 1999; Manzuoli \& Cifuentes, 2013). In this sense, the development of a fund's task condition that simulates a real situation becomes important, since a graduate's readiness to solve professional communication problems is expressed through the ability to solve contextual and practically oriented problems.

The training standard «Pedagogical Education» provides for the formation of the ability to provide spiritual and moral education of students on the basis of basic national values (GPC4) and the ability to interact with participants of educational relationships in the implementation of educational programs (GPC-7).

The key actions in the competence of the GPC-7 are the following: demonstrating the ability to organize, manage situations of communication, cooperation, developing the activity and independence of students, mastering the methods of organizing interaction with students, their parents and other teaching staff and specialists in the implementation of educational programs. From the point of view of our research, these actions can be presented in the content of fund's tasks in the form of questions related to the development of a mini-project or situation of communication, cooperation, contributing to the development of activity, independence, initiative, creative abilities of students. 
In the process of evaluating a graduate's ability to interact with other participants of the educational process, his ability to reasonably select the necessary methods and means of interaction with students, their parents, other teaching staff and specialists, as well as his ability to assess the effectiveness of the use of appropriate tools is taken into account (Bystritskaya \& Dmitriev, 2011; Panova, 2016; Shkerina \& Shipitsyna, 2012).

Let's open up a possible sequence of actions of developers in the process of designing fund's tasks to evaluate the competence of the GPC-7 according to the indicator of achievement of this competence GPC-7.2: Selects and applies forms, methods and technologies of interaction and cooperation of participants of educational relations in lesson activities, extra-curricular activities and correctional work within the framework of implementation of educational programs (Approximate basic educational program, 2017).

From the professional standard of the teacher we will choose the labor action A/01.6. labor action 3. Participation in the development and implementation of the educational organization development program to create a safe and comfortable educational environment (Professional standard, 2013). The choice of this labor action and the GPC-7.2 indicator allows to formulate the following two requirements in the structure of the stock task. The first requirement will be related to the choice of the form of interaction. Then it can be formulated, for example, as follows: Choose an interactive form of interaction with students (forum, wall, chat, blog, tape, portfolio, training course, etc.), define the participants of this interaction, define its goals and objectives. Taking into account the first requirement, the second requirement in the assignment may be related to the definition of the relevant content and reflect the achievement of the graduate in accordance with the UC-4.7 competence achievement indicator: select communication strategies and tactics in business negotiations.

The second requirement can therefore be worded as follows: Develop a content (information environment project). In the content imagine graphic materials - photos, infographics, etc.; video materials - commercials, entertainment spots, descriptive videos, reviews, etc.; text materials - articles, posts on websites, social networks and blogs; audio materials - podcasts, commercials, etc.

In order to consider, the GPC-8.5 indicator of achievement of the GPC-8 fund's task competence, it is advisable to add the following requirement: Develop a content assessment form.

It should be noted that the above requirements for fund's task include various forms of development of pedagogical interaction, as well as variants of their use for solving problems of organizing educational and extra-curricular activities. The possibilities of communication through social media such as: forum, photo, video, audio materials, «bulletin board» and others are described.

At the next stage of constructing a stock job, it is necessary to formulate a situation in which a graduate is asked to perform three jobs based on selected requirements. Here is an example of constructing an appropriate situation that determines the content of the stock market task.

A task based on the GPC-7. 
One of the modern forms of development of pedagogical interaction is social networks. The organizational objectives to be achieved through social networks include the organization of educational and extracurricular activities of students. To achieve these goals, "groups» are created in social networks "VK» or "public page», where the necessary information can be exchanged online, homework, electronic textbooks or reference books can be accessed. In addition, all members of a group or community can express their opinion, post photos, videos, audio materials, and the public page acts as a «bulletin board», and only the creator of the page can edit or comment on the information contained therein. As a graduate of the Pedagogical University, the administration of the educational institution addressed you with a proposal to create a project of information environment for the implementation of the educational program in the classroom or after-school activities and (or) correction work.

The next step of designing a universal fund's task is to define criteria and assessment scale, the development of which is described on the example of building a fund's task based on the general professional competence of GPC-5.

So, the presented fund's task allows to check the level of formation of competencies GPC7, GPC-8, UK-4 in accordance with the indicators of their achievement, mastering which is necessary for the future professional activity of a graduate of a pedagogical university.

\section{Conclusion}

The study presents the author's approach to building a model of fundraising task, which serves as a means of evaluating the competencies of bachelor graduates in the field of «Pedagogical education». The proposed structure of the final state exam and the following method of building the stock tasks based on general professional competencies in combination with universal competencies and considering the teacher's work actions formulated in the professional standard of a teacher are described:

1) In the structure of the final state exam it is necessary to distinguish two forms of final tests: computer testing and presentation of the stock task, which implies summing up the results obtained;

2) The fund's task model based on the selection of two general professional competencies from the seven competencies represented in FSES HE, one of which reflects the ability of a graduate to teach based on scientific expertise (GPC-8). Based on these, the "key actions" of the graduate are defined and a practice-oriented situation is constructed in which the graduate must demonstrate these actions. On the basis of the given situation, three questions related to the implementation of the relevant key actions are formulated;

3) The structure of the fund's task consists of three parts: organizational-methodical, substantive and criteria-evaluation. The organizational-methodological part describes the evaluation objects in the form of corresponding competences and indicators of their achievement, formulates the practice-oriented situation and requirements in the form of tasks for the graduate. 
The substantive part presents the context task itself with three questions. The evaluation criteria and indicators of evaluation are defined in the criterion part, and the evaluation scale is set;

4) Fund's tasks types are defined based on various combinations of key graduate actions in a given subject area. The basis for the typification of tasks is the graduate's professional activities envisaged either in academic or extra-curricular activities.

References

Aizenstat, G.V. \& Stebleva, N.N. (2018). Formation of assessment funds as a necessary condition for the implementation of the main professional educational program. INFORMIO Modern educational technologies in education and culture. 2018 URL: http://www.informio.ru/?id=20\&pid=214

Angrist, J.D., Lavy, V. (2001). Does Teacher Training Affect Pupil Learning? Evidence from Matched Comparisons in Jerusalem Public Schools. Journal of Labor Economics, 19(2), 343-370.

Approximate basic educational program. (2017). Direction of training 44.03.05 Pedagogical education. The level of higher education. Bachelor course. Nizhny Novgorod: NSPU named after K. Minin (Minin University).

Blauberg, I.V. \& Yudin, E.G. (1973). Formation and essence of the system approach. Moscow: Nauka.

Bystritskaya, E.V. \& Dmitriev, S.V. (2011). Technology of diagnostics of professional competences and abilities of students. Education in Nizhny Novgorod, 3, 55-60.

Darling-Hammond, L. (1999). Teacher Quality and Student Achievement: A Review of State Policy Evidence. Washington: Center for the Study of Teaching and Policy - University of Washington.

Efremova, N.F. (2012). Competence in education: development and evaluation. Moscow: national education, Federal Institute of pedagogical measurements.

Exam for teachers: how well will the job for certification. (2020). URL: http://ege.lancmanschool.ru/poleznyie-stati/ege-dlya-uchitelej/ (date of request: 04.04.2020).

Federal state educational standard. (2018). Federal state educational standard in the direction of training 44.03.05 teacher education and higher education undergraduate, approved by the order Ministry of education of Russia from 15 March, No. 125. Moscow: Ministry of Education.

Fedorov, A.A., Paputkova, G.A., Ilaltdinova, E.Y., Filchenkova, I.F. \& Solovev, M.Y. (2017). Model for employer-sponsored education of teachers: opportunities and challenges. Man in India, 97(11), 101-114.

Gruzdeva, M.L. \& Tukenova, N.I. (2019). Analysis of the current state of research and development in the field of building information and educational environments of higher educational institutions. Vestnik of Minin University, 7(2), https://vestnik.mininuniver.ru/jour/article/view/980/718 (date of request: 13.03.2020)

Gustyakhina, V.P. (2009). Contextual approach in professional training of future teachers. Modern problems of science and education, 2, URL: http://www.scienceeducation.ru/ru/article/view?id=1060. 
Ignatiev, V.P., Alekseeva, T.E. \& Bogushevich, I.P. (2019). Basic principles of actualization of Federal state educational standards of higher education. Modern problems of science and education, 6, URL: http://science-education.ru/ru/article/view?id=29378 (дата обращения: 02.04.2020).

Kasprzhak, A.G. \& Kalashnikov, S.P. (2014). Significance of educational results as a tool for modernizing teacher training programs. Psychological science and education, 19(3), 87104.

Khutorskoy, A.V. (2003). Activity as the content of education. National education, 8, 107-114.

Korshunova, N.L. (2014). Activity approach in modern education: essence, problem areas, prospects for implementation. Proceedings of the Voronezh state pedagogical University, 2(263), 55-59.

Manzuoli, C.H. \& Cifuentes, Y.S. (2013). Computing Education Competence in Higher Education: Challenges for Teachers. American Journal of Educational Research, 1(9), 406-412.

Markova, S.M. \& Narkoziev, A.K. (2019). Methods of studying the content of professional education. Vestnik of Minin University, 7(1), URL: https://vestnik.mininuniver.ru/jour/article/view/923 (date of request 09.03.2020)

Modernization of the educational process. (2016). Technology of construction of assessment tools for evaluating educational results: educational and methodological guide. Novgorod: Minin University.

Panova, I.V. (2016). Method of projects in the system of control of educational achievements of students of a pedagogical University. Vestnik of Minin University, 2(15), 12-21.

Perevoshchikova, E.N. \& Lekomtseva, A.A. (2016). Designing a contextual task for evaluating the achievement of educational results. Vestnik of Minin University, 4(17), URL: https://vestnik.mininuniver.ru/jour/article/view/310/311 (date of request 09.03.2020).

Perevoshchikova, E.N. (2016). Conceptual foundations for designing tools for evaluating educational results. Vestnik of Minin University, 2, URL: http://vestnik.mininuniver.ru/upload/iblock/07a/perevoshikova.pdf.

Perevoshchikova, E.N., Samoilova, G.S., Lapin, N.I., Elizarova, E.Y. \& Panova, I.V. (2019). The methodology for developing professional competencies of bachelors in the program «Pedagogical Education». Espacios, 33, URL: http://www.scopus.com/inward/record.url?eid=2-s2.085073026001\&partnerID=MN8TOARS

Piskunova, K.E. \& Erokhina, L.Yu. (2017). General professional competence through the prism of professional standards. Mir nauki online magazine, 5(4), URL: http://mirnauki.com/PDF/37PDMN417.pdf.

Professional standard. (2013). Teacher of preschool, primary General, basic General, secondary General education (Educator). Moscow: Ministry of Labor.

Rebrin, O.I. (2014). Use of learning results in the design of educational programs, third edition, supplemented. Yekaterinburg: Urfu, LLC "Azhur Publishing House".

Shkerina, L.V. \& Shipitsyna, E.N. (2012). Monitoring of students ' competencies: diagnostic maps, portfolios. Higher education today, 7, 19-27

Trushnikova, T.G. (2006). System approach in pedagogy as an innovative basis for the formation of educational space. Man and education, 7, 71-72.

Verbitsky, A.A. \& Kalashnikov, V.G. (2010). Category "context" in psychology and pedagogy. Moscow: Logos. 
Yadryshnikov, K.S., Bystritskaya, E.V., Burkhanova, I.Y., Ivanova, S.S., Stafeeva, A.V., Vorobyov, N.B. (2018). Case-Technology Functions In College Student Vocational Training. Modern journal of language teaching methods, 8(3), 305-316.

Yu-Fen Yang \& Nai-Cheng Kuo. (2020). New teaching strategies from student teachers' pedagogical conceptual change in CALL. System, 20, URL: https://doi.org/10.1016/j.system.2020.102218 